\title{
Students make a plan: understanding student agency in constraining conditions
}

\author{
Laura Czerniewicz $^{\mathrm{a} *}$, Kevin Williams ${ }^{\mathrm{b}}$ and Cheryl Brown ${ }^{\mathrm{a}}$ \\ ${ }^{a}$ Centre for Educational Technology, University of Cape Town, Cape Town, South Africa; \\ ${ }^{b}$ Higher and Adult Education Studies and Development Unit, University of Cape Town, Cape \\ Town, South Africa
}

(Received 11 May 2008; final version received 13 November 2008)

Drawing on Archer's perspectives on the agency/structure relationship, this paper explains situations where students in varied, challenging circumstances find ways to negotiate difficult conditions. It reports on a 2007 study undertaken through a survey at three quite different universities in three South African provinces, addressing inter-related questions on access and use.

Our findings are that on-campus access is generally reported favourably, and off-campus access is problematic and uneven. There is a cluster of students using their cell phones to access the Internet, and using their cell phones for academic purposes, and this is true across socio-economic groups (SEGs). It is especially striking that students from low SEGs do so. The findings show the choices students are prepared to make and the strategies which they find in order to engage online or access the Internet to support their studies.

Archer's nuanced approach to agency and structure helps us begin to make sense of the way that students exhibit a more complex and nuanced way of engaging with the availability of different kinds of technologies, as well as making considered decisions about using ubiquitous technologies in unexpected ways and for purposes for which they may not have been intended. Her concept of reflexivity provides a way of describing how those choices are made in relation to structural conditions and enables us to explain how students are 'persons' showing an inventive capacity to circumvent the constraints imposed by structures.

Keywords: students; Archer; agency; higher education; access; use; ICTs; information and communication technologies; South Africa; cell phones

\section{Introduction}

The context of the study is a South African higher education system clearly committed to preparing university students for participation in the knowledge society, as is evident in numerous policy documents. ${ }^{1}$ However, the response to this rapid worldwide social and economic transformation has occurred simultaneously with the substantial restructuring of a fragmented, divided and unequal sector, the legacy of racially demarcated and differentially resourced apartheid institutions (Department of Education 2001; Gillard 2004).

Additionally, social demands on South African higher education institutions have intensified in recent years. Increased participation by a diverse range of students has

\footnotetext{
*Corresponding author. Email: laura.czerniewicz@uct.ac.za
} 
resulted in massification of the sector within a context of limited or even reduced funding (Maasen and Cloete 2002). As is the case internationally, there are both more and different students entering the sector. ${ }^{2}$

\section{The study}

During 2007, we conducted a survey at three quite different residential universities in three South African provinces. The 2250 student respondents completed a detailed questionnaire relating to their access to Information and Communication Technologies (ICTs), including cell phones, both on and off campus, and their academic and social uses of that technology. It was based on previous research conducted in 2004 in the Western Cape of South Africa (Czerniewicz and Brown 2006). The print-based questionnaire included qualitative (open-ended questions) and quantitative (ranges) data for analysis. Our sample size is congruent with other studies of higher education student access to and use of ICTs such as PEW Research Center and Educause Center for Applied Research (ECAR) (Salaway and Borreson 2007; Horrigan 2008). While the sample is representative of the national student population in demographic terms, we are cautious about assuming that the sample generalises beyond those students sampled and consider our findings indicative rather than conclusive.

The research addressed inter-related questions on access and use. We were interested in identifying enablers and constraints both generally and in relation to actual use. We wanted to know how students use ICTs for social and academic purposes, and were keen to identify distinct student clusters should they exist.

The three institutions from which the respondents were drawn are a mixture of traditional and comprehensive (universities merged with former 'technikons') institutions from rural and urban settings. Institution 1 is a small (8657 students) traditional English language institution that has been disadvantaged historically. Institution 2 is a medium-sized (17,500 students) historically advantaged Afrikaans language institution and Institution 3 is a large (24,061 students), recently merged mix of historically advantaged and disadvantaged institutions of mixed languages. The diversity from this mix provided insight into a highly differentiated student body, varied contexts, different infrastructures and historically distinct backgrounds, thus providing a rich data set.

In the light of the complex historical South African higher education context, we had a particular interest in diversity and student background, and to this end constructed an index of socio-economic group (SEG). ${ }^{3}$ Our sample had roughly a third of students from low, average and high SEG backgrounds respectively. These groups were not, however, spread evenly across the three participating institutions. Students also spoke a variety of home languages with the majority (52\%) being a South African language of African origin (predominantly isiXhosa, seSotho and Setswana) followed by Afrikaans (34\%) and then English (9\%).

We employ a 'thick notion' of access incorporating different kinds of access: technological, practical, social and contextual (see Czerniewicz and Brown 2006). In this paper we focus on the findings regarding technological access, i.e. physical access to computers and other hardware such as cell phones, and practical access which means control over when and to what extent technologies are used. This notion of access also includes concepts such as ease of access and adequacy of technology. We differentiated between social and academic uses, drawing on Laurillard for a typology of academic uses (Laurillard 2002). 


\section{Findings of the study}

In this section, we report on the findings of the study with regards technological access. We report briefly on access to computers on campus, and then focus on offcampus access. We report on cell phone access and use for academic purposes. The respondents were all residential, not distance education students. Our focus is on types and conditions of off-campus access of residential students.

On campus access to computers is reported very positively with 1739 of the 2195 respondents describing it as easy or very easy. This is an important finding for institutional decision-makers who may be reconsidering on-campus investment strategies. It is particularly relevant in the light of the findings that off campus access is reported to be varied and challenging. It is however significant to note that even given this generally positive response, the data suggest that students consider off-campus access essential. It is the nature and complexity of this off campus access that is of particular interest in this paper.

Just over a third of respondents report a high degree of access off campus (Figure 1 ), but this is uneven across institutions. The institution with a large proportion of students from low socio-economic groups also has a large proportion of students with no off-campus access to ICTs.

Student responses suggest that those from low socio-economic groups are more likely to have no or very low access (e.g. a shared computer outside the home and/or not being primary users of available computers) than students from average or higher socio-economic groups (as shown in Table 1).

It is nonetheless significant that just over a fifth of those with no off-campus access are from high socio-economic groups, while for the low socio-economic groups the converse is the case, with just over a fifth of those with high access being from these groups.

In contrast to computer access, cell phone ownership is pervasive $(98.5 \%$ of students report owning one) and ownership is not socially differentiated.

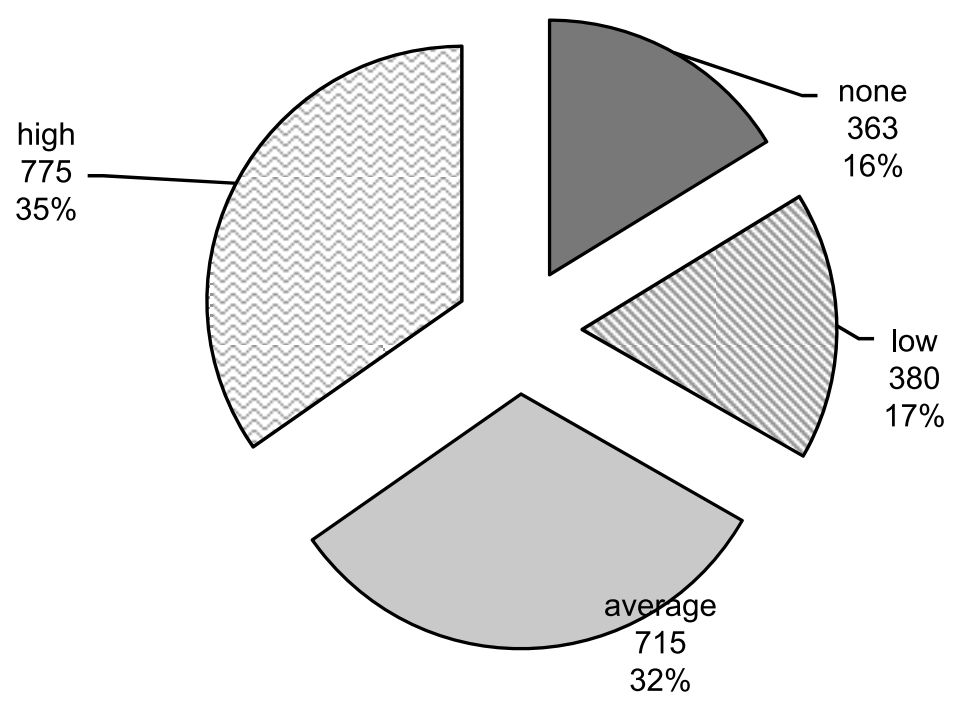

Figure 1. Students' access to ICTs off campus. 
Table 1. Off campus access by socio-economic group (SEG).

\begin{tabular}{lrrr}
\hline & Low SEG & Average SEG & High SEG \\
\hline None & $170(52 \%)$ & $80(25 \%)$ & $79(23 \%)$ \\
Low & $172(48 \%)$ & $111(31 \%)$ & $72(21 \%)$ \\
Avg. & $244(35 \%)$ & $201(31 \%)$ & $232(34 \%)$ \\
High & $167(22 \%)$ & $242(34 \%)$ & $326(44 \%)$ \\
\hline
\end{tabular}

An interesting finding is that despite the cost implications, and the fact that students from a high socio-economic group have other kinds of access to the Internet ${ }^{4}$, the spread of Internet access via cell phone is remarkably even across socio-economic groups (Figure 2).

The fact that cell phones are increasingly being used for Internet access in other sectors is unsurprising (an increase from 58\% to 82\% was reported from 2006 to 2007 in the South African corporate sector (Marsland 2007)), but it is unexpected in the student sector, especially where so many students are under severe financial pressure.

We asked those students who report some access to the Internet off campus how they connected to the Internet. The largest group of students reported using their cell phones rather than other means (Figure 3 ). ${ }^{5}$

Of particular interest is the fact that the most frequent form of Internet access for students from low socio-economic group is their cell phones (Figure 4).

This raises questions about why students are using their own cell phones to access the Internet at their personal expense, in conditions where they are generally very cash strapped. Where does the value lie? In particular, why would students from low SEG backgrounds be prepared to do so?

Given that students report accessing the Internet via their cell phones, this suggests that their use is quite purposeful, and in support of their studies. This supposition is supported by responses from a question specifically about cell phone use where a

low SEG $\square$ average SEG Dhigh SEG

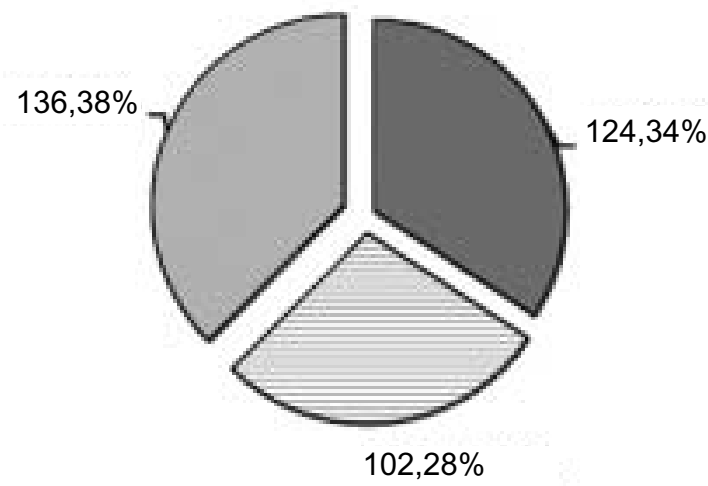

Figure 2. Students who use cell phones to access the Internet off campus by socio-economic group. 


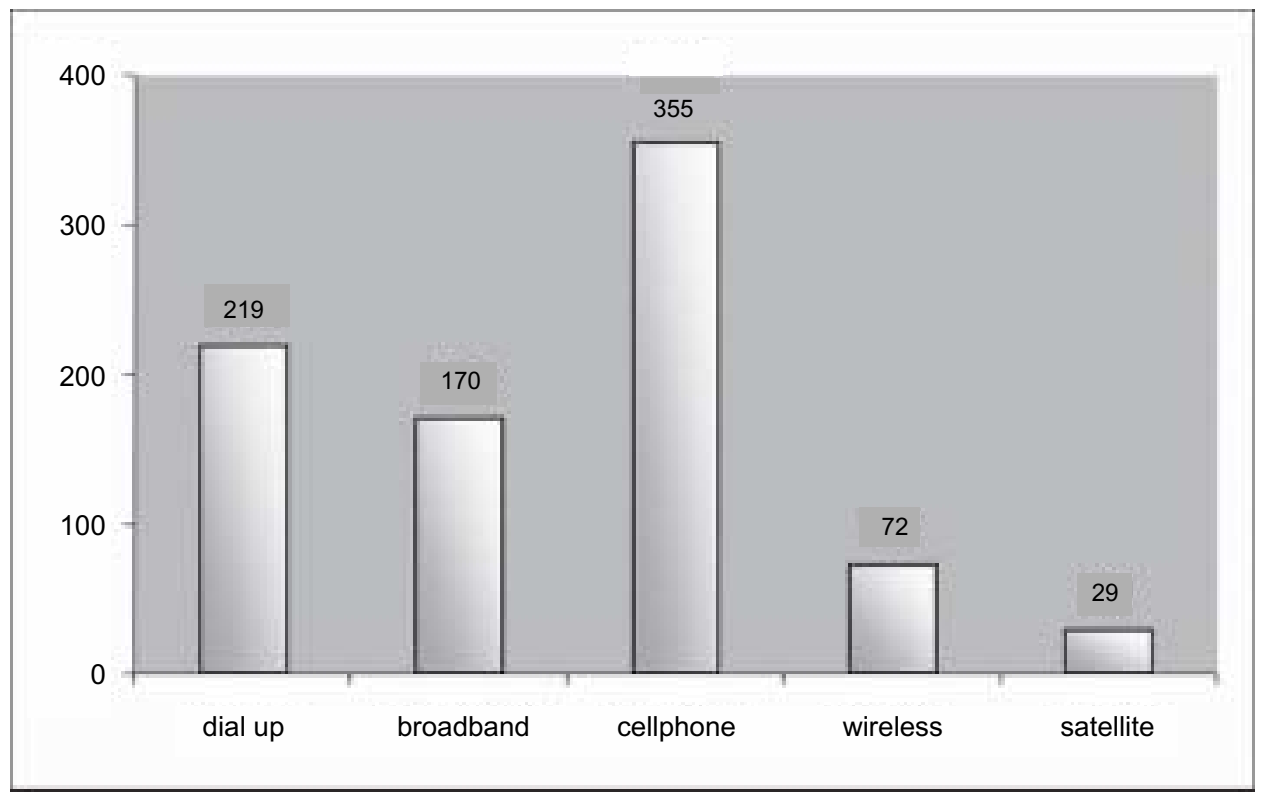

Figure 3. Type of connection off campus by socio-economic group (SEG).

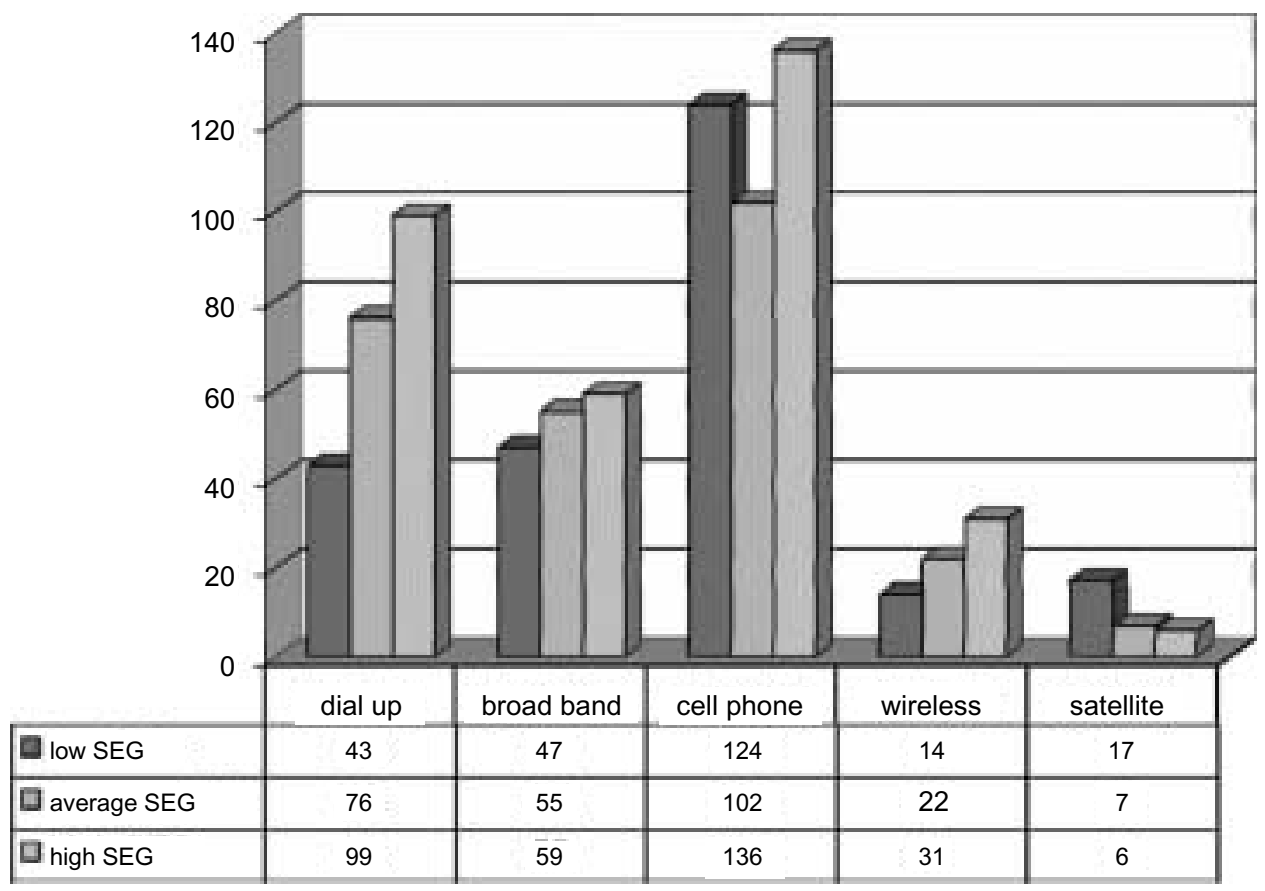

Figure 4. Type of connectivity off campus. 
Table 2. Academic use of cell phones.

\begin{tabular}{lcccc}
\hline & Hardly ever & Sometimes & Often & $(n)$ \\
\hline $\begin{array}{l}\text { Receive information from my university via my } \\
\text { cell phone }\end{array}$ & $884(42 \%)$ & $908(43 \%)$ & $325(15 \%)$ & 2117 \\
$\begin{array}{l}\text { Use my cell phone for something related to my } \\
\text { studies }\end{array}$ & $462(22 \%)$ & $817(38 \%)$ & $841(40 \%)$ & 2120 \\
\hline
\end{tabular}

significant group said they often used cell phones for something to do with their studies $(40 \%)$ and just over a fifth (22\%) said they hardly ever did.

These findings suggest strategic use of available resources. We considered related data to track the relationship between access and types of use. Given that cell phone use is so high, and that so many students report using them for something to do with their studies (Table 2), our attention was focused on cell phone use, in general and in terms of socio-economic group.

The general assumption is that cell phone use is primarily social, and indeed this is a finding in this study. Yet the fact that there is a group of students undistinguished by socio-economic background who use cell phones for academic purposes is of special interest and worthy of investigation. Almost a fifth of those reporting on academic use of cell phones say that this is $40-80 \%$ of their cell phone use, a sizable group who are making deliberate choices. This is striking when contrasted with reports that only two out of 14 South African universities, who participated in a brief survey in late 2007, were exploring the use of mobile technologies to support teaching and learning (Brown et al. 2008).

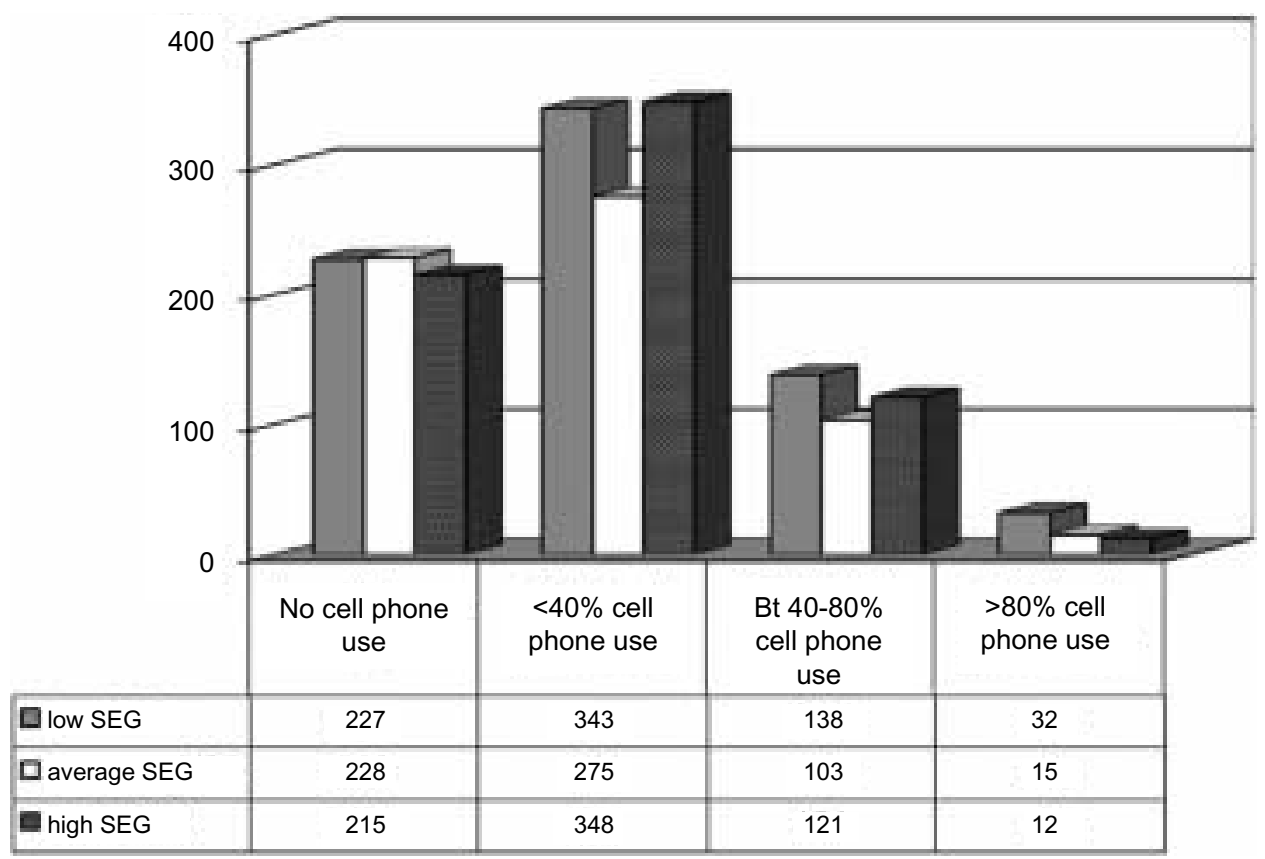

Figure 5. Academic use of cell phones. 
Table 3. Number of courses which use ICTs.

\begin{tabular}{lcc}
\hline & Frequency $(n)$ & $\%$ \\
\hline None & 165 & 8 \\
Very few & 644 & 29 \\
About half & 455 & 21 \\
Most & 692 & 32 \\
All & 227 & 10 \\
$(n)$ & 2183 & \\
\hline
\end{tabular}

Of particular interest is the fact that 59 of the students spend almost all (80-100\%) of their cell phone time on academic activities. While this is not a large percentage of the sample, the existence of such a cluster of responses is of note. When considered by SEG, it is even more noteworthy that of those 59 students, half (32) come from low SEG backgrounds.

Before discussing how one might make sense of students' access choices, it is worth considering potential drivers of their choices. Thus, we see that $63 \%$ of the respondents report that more than half of their courses use ICTs as part of the teaching and learning.

In addition, over two-thirds of the respondents whose courses used ICTs said that their ICT activities counted for marks - 1379 said yes in response to this question, while 613 respondents said no.

These findings raise intriguing issues about the choices available to students, the enabling and constraining conditions in which they operate, the drivers for their use, the choices they make and the basis on which they make their choices.

\section{Discussion}

In brief, we observe a situation where on campus access is generally reported favourably, and off-campus access is problematic and uneven. There is a cluster of students using their cell phones to access the Internet, and using their cell phones for academic purposes, and this is true across socio-economic groups. The findings indicate that some students are especially strategic and committed with regard to access, especially to the Internet. The spread of Internet access via cell phone is remarkable, even when students have other options available to them. The use of cell phones for Internet access by students from low SEGs is particularly striking in the light of their often severely constrained circumstances and the relatively high cost of cellular access both in terms of cell phones with this capacity, and actual usage costs.

How does one make sense of these findings? What makes it worth it for these students, especially those from poor backgrounds to make choices to use technologies in ways which require a sacrifice on their parts? Why is it that in these difficult conditions, so seriously constraining in real ways, some students are able to overcome structural challenges which would seem to determine their actions? And how has it come about that students are using their cell phones for academic purposes when this was not the original intention of these tools, which one assumes are generally used for social purposes?

The data from the study reported on in this paper cannot on its own inform deep explanations. We can only offer tantalising pointers provided by the responses to the 
open ended questions. It will therefore, inevitably, suggest further research to provide answers to the 'why' questions suggested by the clusters of responses seen in the findings.

The most common interpretation of the findings in this paper would be provided by the logic of the 'digital divide'. This has often served as a way to identify and perhaps describe some consequences of social structural constraints on, and enablements of, ICT usage by students in developing countries and assumes that lack of physical access to ICTs is based on social constructs such as race, ethnicity, age, income etc. (Warschauer 2003). These are determinants over which individuals have no personal control, and where inclusion or exclusion is socially determined. Thus such a binary notion leaves individuals trapped into socially deterministic modes of reaction, dependant on 'outsiders' to liberate them by providing them with access to ICTs. Agency is suffocated under the weight of social structure.

However, what emerges from the research reported on in this paper, resists the simple reduction of the digital divide, which tends to deprive students of agency. Rather, the findings indicate that the students 'make a plan', a metaphor drawn from the South African Afrikaans expression 'maak 'n plan' which connotes an ability to respond smartly to adverse circumstances. It is clear that students exhibit a more complex and nuanced way of engaging with the availability of different kinds of technologies, as well as making considered decisions about using ubiquitous technologies in unexpected ways and for purposes for which they may not have been intended. Certainly the availability of ICT technologies creates such structural constraints and enablements, and without them the students would not be in a position to 'make a plan'. The social realist point, however, is that the digital divide 'haves/have-nots' description does not exhaust the explanatory possibilities, it merely describes the objective circumstances in which students-as-agents must live. Indeed, as other researchers have noted, "though much research sheds light on the structure-action relationship, it does not illuminate users' biographical realms and reflexivities. In consequence, some genuine motives in ICT-related practices remain poorly understood" (de Vaujany 2008).

The literature on ICTs in education in general and in developing countries in particular provides numerous examples of studies of social conditions. In developing country contexts the ways that computer use is especially constrained by circumstance have received considerable attention. Given the real and demanding challenges faced by students in such contexts, this is understandable. The problem is that this linear, determinist approach assumes that by creating enabling conditions, actions will automatically change. This view leads to strategies premised on the belief that If We Build It They Will Come. A project which preceded this research found that while ICT use is constrained by lack of access, it is not necessarily enabled by access (Czerniewicz and Brown 2009). The findings reported here suggest that even in constraining circumstances, students find ways of 'overcoming the odds' to meet their objectives. Thus on both counts, the power of structure to determine action is challenged.

What is needed is a theoretical perspective which provides a way to examine the social reality of students' use of ICTs by creating ontological, methodological and theoretical space to analytically separate structure from agency. As with de Vaujany, although independently from him, we suggest that Margaret Archer's social realism provides just such a theoretical lens (Archer 1995, 2000, 2002, 2003, 2007). 
Like Giddens (1996), Archer rejects the old sociological dilemma of structural determinism versus voluntarism by claiming the mutual dependence of structure and agency. However, in contrast to Giddens' structuration theory which collapses structure and agency together in the action of 'social interaction' (Giddens 1996, 101), Archer's social realism provides the basis for an 'analytical dualism' based on the recognition that structure and agency are sui generis different kinds (Archer 1995). Analytical dualism is a 'theoretical necessity' (and not a philosophical dualism) that enables the examination of the processes of structural elaboration (structuring and re-structuring) that occur over time (Archer 1995, 157).

Rooted in what Archer terms an 'emergentist ontology' (objects possess powers brought about by the conjunction of two or more elements, but these powers cannot be explained by reduction to their components), social realism recognises social reality as stratified: agency cannot be reduced to structure, nor vice versa. Furthermore "structure necessarily pre-dates the action(s) which transform it ... and ... structural elaboration necessarily post-dates those actions which have transformed it..." (1995, 157). Agents thus do not produce and reproduce society, but rather 'reproduce or transform' society (Archer 1995, 140): but always on the basis of something that was already there, albeit the result of "the activities of the long dead" (Archer 1995, 143).

This combination of temporal distinction and emergence permits freedom from social determinism, individualist voluntarism and the elision of structure and agency in action. This freedom allows for the practical examination of each of the strata in sociological analysis, without denying their interdependence.

As Archer herself notes, social realist theory is useful for understanding the ways that the causal power of social forms is mediated through social agency (Archer 2003). Thus the notions of constraints and enablements themselves imply agential powers. Only because people envisage particular courses of action can one speak of their constraint or enablement, and only because they may pursue the same course of action from different social contexts can one talk of their being differentially constrained or enabled (Archer 2003, 4).

The particular value of Archer's work is her interest in the relation between agency and structure from the perspective of the agent, or the person. In summary, she argues that the process of mediation between structure and agency must be considered as entailing three stages, which capture the interplay between objectivity and subjectivity, as follows:

(1) structural and cultural properties objectively shape the situations which agents confront involuntarily, and possess generative powers of constraint and enablement in relation to;

(2) agents' own configurations of concerns, as subjectively defined in relation to the three orders of natural reality - nature, practice and society;

(3) courses of action are produced through the reflexive deliberations of agents who subjectively determine their practical projects in relation to their objective circumstances. (Archer 2003, 135)

This provides a useful way of reading the findings of the study. In particular, it points to an examination of the ways that courses of action are produced through the reflexive deliberations of agents who subjectively determine their practical projects in relation to their objective circumstances. Furthermore, for anything to exert the power of a constraint or enablement it has to stand in a relationship such that it obstructs or 
aids the achievement of some specific agential enterprise or 'project'. "A project involves an end that is desired ... and some notion ... of the course of action with which to accomplish it" (Archer 2003, 6).

Thus, in the case of this research, the conditions of access off campus for students are real constraints, just as the backgrounds of those from low SEGs genuinely locate them in challenging circumstances (point 1, above). However, students' experience of these constraining factors are mediated by their own constellations of concerns (point 2 ), and what students actually do occurs as a result of individual reflexive processes in which their concerns are considered in relation to the objective reality of structural enablers and constraints (point 3).

As mentioned, a number of papers address what Archer describes as the first stage of examination, the way(s) in which structural emergent properties shape "our situations such that they have the capacity to operate as constraints and enablements" (Archer 2003, 132). This the digital divide does well.

The next stage of examination considers the ways in which "... agents, in virtue of their reflexivity ... deliberate about the circumstances in relation to their own concerns. Agential subjectivity reflects upon societal objectivity" (Archer 2003, 133). This does not suggest that agential subjectivity is infallible, but it is through this examination of the objective circumstances in which we are placed, and which are 'not of our choosing', that we prepare for the next stage in the process:

\footnotetext{
... we consult our projects which were deliberatively defined to realise our concerns; and we strategically adjust them into those practices which we conclude internally (and always fallibly) will enable us to do (and be) what we care most about in society... This final stage of mediation is indispensible because without it we can have no explanatory purchase upon what exactly agents do. Deprived of such explanations ... [we have] ... to settle for empirical generalisations about 'what most people do most of the time...' (Archer 2003, 133)
}

While this seems obvious, it challenges the adequacy of simple have/have-not explanations to explain ICT usage by students. Because agents can and do reflexively engage in projects which arise out of their concerns, society remains an open and contingent system (Archer 2003). Socially deterministic explanations remain blunt instruments of explanation, because they do not "...distinguish between the existence of structural properties and the exercise of their causal powers" (Archer 2003, 7, original emphasis).

Using Archer's language, one would ask, "What is the "project" in which students are engaged?' Are there any indications or pointers in the existing data? Then, noting the constraints which realistically limit students' activities in terms of limited, unavailable and inadequate off-campus access, how are the causal powers activated of those students who are not passive recipients of their circumstances in which they find themselves?

Access is difficult, but there are benefits, and there are some indications in this data of the specific ways in which students find ICTs and the Internet useful. Thus, they are convenient ("Don't have to pile huge volumes of books - hard copies - on my desk. All that can be retrieved from micro chips", 1-268) and they save students from potentially embarrassing situations ("You don't always have to confront your lecturers as you can get most answers online", 1-62). In addition, cell phones have uses beyond the obvious, i.e. "[I] use a calculator on the phone" (1-114), and "[I] Save facts on my phone (text)" (2-672). 
However, there is a larger project suggested in some of these responses that goes beyond such instrumentalist expressions of use. Comments such as the following suggest a life project: "I feel computer skills are very essential as we are headed towards a strongly computerised civilization" (1-283); "ICTs form part of our modern lifestyle, it is the new 'language' everybody understands" (3-306); "it gives me the skills I need for future use" (3-197); "it is so great because it makes someone marketable" (2-56); and indeed, "I only do it because it will benefit me in the future, otherwise I hate computers" (1-468).

While data of this kind can only be preliminary, the comments above suggest that computers are the means to a 'better' life, to success in the market place and possibly to future financial security.

The final student comment above is fascinating because it casts technology in such a negative light, yet the student's commitment to their project, their investment in their future, is a powerful driver. This exemplifies Archer's assertion that “... the activation of causal powers is contingent on agents who conceive of and pursue projects upon which they would impinge" (Archer 2003, 7).

Archer also notes that when a project is constrained "... during its execution agents can act strategically to discover ways round or to define a second best outcome ..." $(2003,6)$. In this study, the system is challenged by a student creatively evading the constraints imposed by the objective reality in which the student finds him/herself: “... using a blue tooth phone with airtime will help you access to ict through internet" [sic] (2-128).

Students also exhibit their agential power by circumventing structural constraints. As Archer notes “... the influences of constraints and enablement will only be tendential because of human reflexive abilities to withstand them and circumstantially to circumvent them ..." $(2003,7)$. In this case challenges to the system occur, for example, through a student ignoring the affordances of ICTs: "As daar geen ander alternatief is nie is dit goed. Maar ek persoonlik verkies boeke as ' $n$ rekenaar" ["If there is no other alternative it [ICT] is good. But I personally prefer a book to a computer"] (3-695). In this case the student's concerns result in him/her engaging in the project of studying in such a way that - at least when there is an alternative (under his/her own description) - that neither structural enablements nor constraints are activated.

The emotional investment is of note here. As Mutch notes (2007, 1128), Archer places considerable emphasis on the emotional commitments of the person who is conceived as a strong evaluator of moral projects (Mutch 2007). The focus then is on the end not the means as the prime concerns of persons who engage in and reflectively on their personal projects. The reflection takes place in the form of an internal conversation, and it is this which suggests why some persons come into evade or challenge structures.

Ignoring or evading the constraints on a project, however, carries "objective opportunity costs" (Archer 2003, 136). For the student respondents evading the constraints of limited off-campus access these opportunity costs translate very literally into time, effort and resources: "I have to travel for 30 kilometers and pay ten rands for the taxi fare and after that I still have to pay 10 rands for 30 minutes using the internet" (1-93). ${ }^{6}$

These opportunity costs arise in part because the decisions that students (and indeed all social actors) make are made under their own descriptions and as such are fallible. However, they arise also because the decisions are made from within the situations not of our choosing in which we unavoidably find ourselves as agents 
("collectivities sharing the same life chances": Archer 2003, 133, n. 2). Thus: "When you go to the lab, you get there everyone busy with computers others are waiting and you have to decide whether you go or skip the lecture" (1-76). As Archer notes, the costs of engaging in a project are differential across groups. Thus for students from high SEGs, the cost-to-the-student of accessing the internet is lower than for students from low SEGs, but as she notes, "such pricing is ... objective and failure to allow for it can simply derail strategic action" $(2003,136)$.

What of that specific cluster of 32 students from low SEGs who use their cell phones for academic purposes? A closer look at the data indicates that this group experiences the most difficult conditions on campus (one of them comments that "the lab is infested with people", 1-57); that 10 students report sharing the computer they have access to off campus with four or more people, and 25 describe their off-campus use as difficult/very difficult. They may be driven to use expensive cell phone time by course requirements (24 say their ICT course activities count for marks); or they may be motivated by their bigger projects, their longer-term life concerns. All students have the "properties and powers to monitor their own life, to mediate structural and cultural properties of society" (Archer 2000, 19). These particular students have made sacrifices and trade offs. They are from poor backgrounds, yet they choose to use their limited funds for academic purposes. Archer's concept of reflexivity provides a way of describing how those choices are made in relation to the structural conditions when she points out that the subject is conducting an endless assessment of whether the price to be paid for devotion to a project is worth paying and whether the price which was paid for subordinating and accommodating other concerns is still one with which the subject can live (Archer 2002, 19).

These students are 'persons' showing an inventive capacity to circumvent the constraints imposed by structures. It is as persons with personal and body embedded life histories that their biographical accounts can be told. The level of description to be pursued extends beyond that of actors who are related to a social group with specific interests and strategies, and beyond agents with shared cultural economic and demographic features (Archer 2003). It is these biographies, these personal accounts which further research must uncover.

\section{Conclusion}

This paper set out to report the findings of a study of student access and use informed by Archer's social realist theory, particularly pertinent in the light of the constraining and enabling factors reported on and the ways that students engage with them. While the research methodology did not allow for deep explanations, the data clarified the possibilities. Particularly noteworthy are the findings which show the choices, even sacrifices, students are prepared to make and the strategies which they find in order to engage online or access the Internet. The areas for further research are foregrounded both by the data and by the theoretical dimensions of Archer's work.

Archer provides us with a means to show how students as persons are able to find ways to evade, endorse, repudiate or contravene enablements and constraints on their projects (Archer 2003, 131). The students are influenced by, but not determined by, the barriers they face. They are not influenced in the same way by social structures simply by being part of a broader group, nor do they respond in the same way. Similarly, while conditions can profoundly influence the attitudes and behaviour of actors, all students do not experience an equal measure of freedom to respond. 
Biographical studies will be valuable to specify the causal mechanisms which underlie different agential responses.

Archer $(2007,93)$ also offers a typology of reflexivity shaped by the interplay between the social situation and the personal projects of the agents. This is a sociological concept of reflexivity albeit one underpinned by the cognitive affordances possessed by embodied agents. Indeed as, Mutch $(2007,119)$ notes, differential access to resources may be of considerable significance to this interplay. Two of these four reflexivity categories present a promising lens through which to view the findings of this study and their further investigations: the autonomous reflexives who sustain internal conversations leading directly to action, and the fractured reflexives whose internal conversation may lead to disorientation, rather than purposeful action, with life chances being determined to a large extent by their involuntary social positioning.

The findings reported in this paper have only hinted at the latter category, those fractured reflexives who remain victims of circumstances, but the data points decisively to a cluster of students whose behaviour would define them as autonomous reflexives. The strategies described in this paper show how this group has been able to circumvent the constraints that would normally limit their projects, by using cell phones for academic purposes, and by making strategic choices in favour of their long-term futures. Why they do so, how they are unique, how those interplays of context, social identity and personal identity play out - such explanations would require individual student stories. Archer's theory of the relationship of agency and structure would provide a rich and valuable framework to deepen our understanding of these important biographical accounts.

\section{Notes}

1. National Plan for Higher Education (Department of Education 2001), the National Research and Development Strategy (Department of Arts Culture Science and Technology 2002), the National Research and Technology Foresight ICT Report (Department of Science and Technology 2000), and the White Paper on e-Education (Department of Education 2003).

2. Students' enrolments increased by $30 \%$ from 569,000 in 1995 to 744,489 in 2004 . The ratio of black student enrolments increased from 52\% in 1993 to 74\% in 2004 (HEMIS 2003; Council on Higher Education 2004; HEMIS 2004).

3. The socio-economic group index was calculated based on a cumulative score of three items: (1) occupation of primary breadwinner; (2) highest education level of primary breadwinner; (3) if respondent was the first person in their immediate family to go to university.

4. High socio-economic group students use a mix of dial-up (29\%) and broadband (17\%).

5. Students chose one answer, their most dominant form of connection.

6. These (literal) costs reflect 2007 figures in South African Rand. It is, however, important to note that costs are not restricted to material costs, but include such costs as relationships, self-concept, opportunity etc. So for this student, costs may include time with family and friends.

\section{References}

Archer, M. 1995. Realist social theory: The morphogenetic approach. Cambridge, UK: Cambridge University Press.

Archer, M. 2000. Being human: The problem of agency. Cambridge, UK: Cambridge University Press.

Archer, M. 2002. Realism and the problem of agency. Journal of Critical Realism 5, no. 1: $11-20$. 
Archer, M. 2003. Structure, agency and the internal conversation. Cambridge, UK: Cambridge University Press.

Archer, M. 2007. Making our way through the world: Human reflexivity and social mobility. Cambridge, UK: Cambridge University Press.

Brown, C., H. Thomas, A. van der Merwe, and L. van Dyk. 2008. The impact of South Africa's ICT infrastructure on higher education. In Proceedings of the 3rd international conference of e-learning, ed. D. Remenyi, 69-77. Cape Town, South Africa: Academic Publishing.

Czerniewicz, L., and C. Brown. 2006. The virtual Möbius strip. Research Report Series 1. Cape Town, South Africa: University of Cape Town. http://www.cet.uct.ac.za/virtualmobius

Czerniewicz, L., and C. Brown. 2009. A virtual wheel of fortune? Enablers and constraints of ICTs in higher education in South Africa. In Bridging the knowledge divide: Educational technology for development, eds. S. Marshall, W. Kinuthia and W. Taylor. Charlotte, NC: Information Age Publishing.

de Vaujany, F. 2008. Capturing reflexivity modes in IS: A critical realist approach. Information and Organisation 18, no. 1: 51-72.

Department of Arts Culture Science and Technology. 2002. South Africa's national research and development ( $R$ and $D)$ strategy. Pretoria, South Africa: Government Printers.

Department of Education. 2001. The national plan on higher education. Pretoria, South Africa: Government Printers.

Department of Education. 2003. White paper on e-education: Transforming learning and teaching through ICT. Pretoria, South Africa: Government Printers.

Department of Science and Technology. 2000. National Research and Technology Foresight ICT report. Pretoria, South Africa: Government Printers.

Giddens, A. 1996. In defence of sociology. Essays, interpretations and rejoinders. Cambridge: Polity Press.

Gillard, E. 2004. Report on the colloquium on 10 years of democracy and higher education change. http://www.che.ac.za/documents/d000085/GillardColloquiumReport-4February 2005.pdf

Horrigan, J. 2008. Mobile access to data and information: PEW internet and the American Life project. http://www.pewinternet.org/pdfs/PIP_Mobile.Data.Access.pdf

Laurillard, D. 2002. Rethinking university teaching. 2nd ed. London: Routledge Falmer.

Maasen, P., and N. Cloete. 2002. Global reform trends in higher education. In Transformation in higher education. Global pressures and local realities in South Africa, eds. N. Cloete, R. Fehnel, P. Maassen, T. Moja, H. Rerold, and T. Gibbon, 13-58. Cape Town, South Africa: Juta and Company.

Marsland, L. 2007. The tipping point for mobile is near. http://www.bizcommunity.com

Mutch, A. 2007. Reflexivity and the institutional entrepreneur: A historical exploration. Organization Studies 28, no. 7: 1123-40.

Salaway, G., and J. Borreson. 2007. The ECAR study of undergraduate students and information technology, 2007. Educause Center for Applied Research. http://net.educause.edu/ir/ library/pdf/ers0706/rs/ERS0706w.pdf

Warschauer, M. 2003. Demystifying the digital divide. Scientific American 289, no. 2: 42-7. 